\title{
Strategi Penelitian Dan Pemanfaatan Data Kubur Bagi Studi Wilayah Di Bali
}

\section{Fadhila Arifin Aziz}

Keywords: cultural resource management, planning, sites, prehistory, development

\section{How to Cite:}

Aziz, F. A. (2000). Strategi Penelitian Dan Pemanfaatan Data Kubur Bagi Studi Wilayah Di Bali. Berkala Arkeologi, 20(1), 66-77. https://doi.org/10.30883/jba.v20i1.808

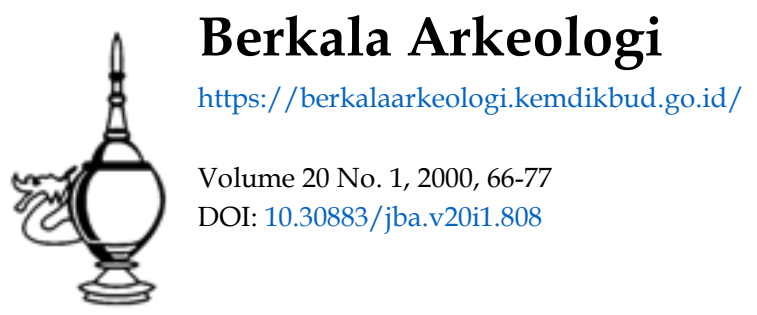

\section{c) (ㅇ) ()}

This work is licensed under a Creative Commons Attribution-NonCommercial-ShareAlike 4.0 International License. 


\title{
STRATEGI PENELITIAN DAN PEMANFAATAN DATA KUBUR BAGI STUDI WILAYAH DI BALI*
}

\author{
Fadhila Arifin Aziz \\ (Pusat Arkeologi)
}

\section{Pendahuluan}

\begin{abstract}
Akhir-akhir ini disiplin arkeologi mengembangkan konsepsi penataan ruang. Kegiatan manusia masa lampau ditinjau baik dari aspek permukiman, perdagangan, subsistensi, geografi, maupun idcologi. Pergeseran minat dari aspek bentuk dan aspek waktu suatu artefak, atau prinsip 'orientasi artefak' dan 'orientasi situs', kemudian berkembang menjadi 'orientasi wilayah'. Perhatian terhadap aspek ruang benda-benda arkeologi dalam suatu kawasan diterapkan pula dalam orientasi kebijakan penelitian arkeologi di Indonesia, khususnya lingkup Pusat Penelitian Arkeologi Nasional. Ketidak-puasan terhadap penjelasan hasil penelitian yang terbatas hanya pada satu situs secara individual, telah mendorong keinginan untuk memperoleh penjelasan lebih mendalam, misalnya bagaimana manusia masa lampau melakukan aktivitas dan memilih lahan tempat hunian, penguburan, subsistensi, atau bagaimana suatu masyarakat
\end{abstract} berhubungan dengan masyarakat lainnya.

Orientasi wilayah (regional oriented) merupakan suatu kecendrungan untuk mengamati gejala-gejala arkeologis tidak hanya terbatas pada ruang 'situs' sebagai satuan analisis, melainkan mencakup 'sejumlah situs atau ruang antarsitus" sebagai satuan analisis. Kajian wilayah (regional study) merupakan salah satu bentuk implimentasi dari kajian Arkeologi Ruang (spatial Archaeology siudy) yang memandang kesatuan wilayah diikat oleh kesatuan atau kemiripan sosial, politik, dan budaya. Implikasi dari pengertian di atas, maka kajian wilayah dalam arkeologi dipandang sebagai ruang distribusi situs-situs yang mencakup batasan relasi wilayah budaya, dan terdiri atas sckelompok ruang-ruang (fisik) tempat manusia melakukan aktivitasnya pada masa lampau. Distribusi ruang ini biasanya tersusun dalam suatu sistem tata ruang, sehingga kajiannya dapat ditinjau berdasarkan berbagai aspek dan dapat dipelajari dari sudut berbagai disiplin (multidisiplin). Melalui tinggalan bendabenda arkeologi yang tersebar dalam lokasi suatu situs, satuan wilayah, ataupun suatu kawasan maka seorang arkeolog dapat mendeskripsikan serta menganalisis bentukbentuk persebaran dan hubungan antarwilayah, baik dalam skala horisontal maupun vertikal, untuk selanjutnya menafsirkan dan menjelaskan mengapa terjadi persebaran tinggalan arkeologi.

- Pemah dipresentasikan dalam Evaluasi Hasil Penelitian Arkeologi, 20-26 September 1996. di Ujung Pandang. 
Ruang adalah salah satu dimensi dalam lingkup arkeologi yang juga memperhatikan tata letak permukiman manusia masa lampau pada satuan wilayah lingkungan tertentu, mencakup aspek lingkungan fisik (biotik dan abiotik) dan budaya yang tercermin pada benda-benda peninggalan purbakala. Komponen dalam permukiman masa lampau yang tercermin dalam kegiatan dan sebaran okupasi dapat bercirikan aktivitas yang bersifat hunian, perburuan, perbengkelan, penguburan, pemujaan, pasar, dan lain-lain dalam satuan ruang dan waktu tertentu. Bila konsep wilayah (region) diaplikasikan dalam arkeologi permukiman, maka bentang ruang tempat orang bermukim secara fisik (wilayah geografis) diasumsikan sebagai hubungan yang bersifat timbal balik dengan komponen-komponen yang ada di dalam sistem permukiman (wilayah budaya).

Salah satu komponen permukiman adalah aktivitas penguburan, memiliki karakteristik berupa temuan rangka dengan berbagai teknik dan cara penguburan dijumpai hampir di seluruh wilayah Indonesia. Data kubur pada bentang alam tertentu dalam kajian wilayah memiliki nilai strategis sebagai sumberdaya arkeologi yang berguna untuk meng-gambarkan, menjelaskan, dan memahami tingkahlaku serta interaksi manusia, khususnya aspek religi/kepercayaan. Karakteristik kewilayahan, khususnya aspek penguburan pada konteks mekanisme perkembangan dan perubahan budaya setempat di berbagai wilayah Indonesia dapat diidentifikasi dengan mencari persamaan dan perbedaannya. Menurut Huntington dan Metcalf, penelitian terhadap situs-situs yang mengandung data kubur berkaitan dengan studi tentang masalah-masalah sosial, budaya, kronologi, etnik, ras serta makna dan ekspresi.

Kubur sebagai salah satu bentuk peninggalan aktivitas manusia di masa lampau ditemukan baik di daerah pantai yang landai, di dalam gua-gua yang memiliki ruangan, ataupun di lereng-lereng pegunungan. Pemilihan lokasi penguburan seringkali didasarkan pada beberapa faktor, misalnya faktor budaya (religi, teknologi, organisasi sosial) dan faktor alami (naluri, instink). Pada awalnya aktivitas penguburan merupakan upaya untuk menyingkirkan mayat dari lingkungan orang yang masih hidup. Meskipun demikian, pertumbuhan populasi dan teknologi mengakibatkan manusia kemudian menata lahan yang tersedia berdasarkan persepsi budayanya masing-masing. Demikian pula peninggalan arkeologi berupa kubur-kubur meninggalkan jejak budaya secara berpola dalam satuan ruang. Oleh karena itu tidaklah heran bila lokasi penguburan kadang-kadang merupakan pencerminan hubungan yang bersifat fungsional dalam suatu wilayah pemukiman.

Tujuan penelitian karya ilmiah ini adalah melakukan tinjauan bagaimana data kubur di beberapa situs dapat dimanfaatkan sebaik-baiknya untuk mengkaji suatu wilayah dalam konteks ruang budaya, serta beberapa pandangan penerapan dan pengembangan kerangka penelitian situs kubur. Beberapa situs yang mengandung data kubur yang dijadikan obyek pengamatan di sini terbatas beberapa situs dari wilayah Bali, antara 
lain Gilimanuk (Jembrana), Tigawasa, Busungbiu, Bondalem (Buleleng), Kalanganyar (Seririt), dan Semawang (Badung). Situs-situs di atas sejak dulu telah menjadi lokasi pemukiman yang terbukti dengan jenis dan keragaman temuan bercirikan aktivitas penguburan bercorak tradisi prasejarah.

\section{Strategi Penelitian Beberapa Situs Berkarakteristik Kubur di Bali}

Situs Busungbiu berada di daerah pegunungan dan termasuk Desa Busungbiu, Kecamatan Banjar, Kabupaten Buleleng. Secara morfologi lokasi Situs Busungbiu berada pada satuan lahan perbukitan atau daerah kaki bukit dengan ketinggian 255 meter dari permukaan air laut, atau berada pada koordinat $8^{\circ} 9^{\prime} 45^{\prime \prime}$-. $8^{\circ} 12^{\prime} 44^{\prime \prime}$ Lintang Selatan. Pada tahun 1928, V.E. Korn menerima laporan penduduk setempat, dan selanjutnya sampai kini pengumpulan data masih dilakukan melalui kegiatan ekskavasi.

Hasil ekskavasi di Situs Busungbiu mengacu pada karakteristik temuan kubur terbuka dengan wadah berupa sarkofagus. Sarkofagus di Busungbiu ini berukuran kecil dengan penampang lintang setengah lingkaran atau setengah bulat-panjang. Biasanya, bagian tutup dan wadah sarkofagus memiliki tonjolan sebuah di tengah-tengah bidang depan dan sepasang tonjolan berdampingan di bidang belakang (gaya Busungbiu). Di dalam sarkofagus ditemukan rangka manusia dengan sikap terlipat dan posisi miring ke salah satu sisi, disamping juga terdapat bekal kubur berupa gelang dan mata tombak perunggu. Menurut Soejono, gaya Busungbiu di atas memiliki perkembangan terbatas di daerah pegunungan beratdaya Singaraja serta sebelah barat Danau Bujan dan Tamblingan (Soejono 1962:3; 1977).

Situs Tigawasa termasuk Desa Tigawasa, Kecamatan Banjar, Kabupaten Buleleng, atau berada pada koordinat $8^{\circ} 11^{\prime} 28^{\prime \prime}-8^{\circ} 11^{\prime} 05^{\prime \prime}$ Lintang Selatan. Lokasi situs ini secara morfologis berada pada satuan daerah perbukitan atau pedataran bergelombang kuat dengan ketinggian 500-800 meter dari permukaan air laut. Penelitian di Situs Tigawasa pertama kali dilakukan pada tahun 1976 setelah mendapat laporan penduduk setempat mengenai temuan 2 buah sarkofagus, dan sampai kini kegiatan pengumpulan data berupa survei dan ekskavasi masih terus dilakukan. Jarak Situs Tigawasa dengan Situs Busungbiu sekitar $8,75 \mathrm{~km}$.

Hasil ekskavasi selama 5 tahap menunjukkan karakteristik temuan di Situs Tigawasa adalah kubur terbuka dengan menggunakan wadah (sarkofagus). Sarkofagus Tigawasa memiliki penampang lintang setengah lingkaran dengan tonjolan bulatan tebal dan gepeng pada bagian belakang, baik bagian wadah maupun tutupnya dan memiliki bentuk yang sama dengan sarkofagus di Situs Busungbiu. Di dalam sarkofagus ditemukan kubur sekunder rangka manusia dengan benda bekal kubur ditemukan di 
luar dan di dalam sarkofagus meliputi jenis periuk (polos dan hias tera jaia), fragmen tajak, antiing-anting, cincin dan lempengan pentagonal perunggu, mata tombak besi, serta keramik asing.

Situs Kalanganyar termasuk dalam dusun Kalanganyar, Desa Banjar Asem, Kecamatan Seririt, Kabupaten Buleleng, atau berada pada koordinat $8^{\circ} 7,35^{\prime \prime}-8^{\circ} 10^{\circ}$ 52" Lintang Selatan. Lokasi situs berada pada undakan tertinggi (teras I dan II) lahan pedataran aluvial pantai dan secara morfologis termasuk dalam satuan dataran rendah. Ketinggian Situs Kalanganyar 25 meter di atas permukaan air laut dan selalu dipengaruhi pasang surut. Penelitian di Situs Kalanganyar dilakukan sejak tahun 1989, 1991, 1993, dan 1995 dengan tujuan menggambarkan aspek kehidupan masa lampau dengan melengkapi data kubur situs. Jarak Situs Kalanganyar dengan Situs Busungbiu $\pm 10,25 \mathrm{~km}$, dan jarak Situs Kalanganyar dengan Situs Tigawasa $\pm 14,37 \mathrm{~km}$.

Hasil ekskavasi yang diperoleh dari 4 tahap penelitian di Situs Kalanganyar menunjukkan karakteristik situs penguburan terbuka dengan wadah sarkofagus dan penguburan terbuka tanpa menggunakan wadah. Rangka manusia yang ditemukan dalam sarkofagus memiliki posisi terlipat dengan kepala berada di sebelah tenggara dan mengarah ke Gunung Asah, dan kaki berada di sebelah baratlaut. Jenis bekal kubur antara lain berupa periuk (hias terajala, gores, cukil, dan polos), pelandas dari bahan tanah liat bakar, tajak, serta benda-benda yang terbuat dari perunggu seperti kapak genggam, gelang, cincin, anting-anting, dan ikat pinggang berbentuk spiral. Sarkofagus yang ditemukan di Situs Kalanganyar berukuran kecil tanpa hiasan dengan penampang lintang setengah lingkaran, serta sebuah tonjolan bulat gepeng pada bidang depan di bagian kepala dan dua buah tonjolan pada bidang sempit di bagian belakang (gaya Angantiga) (Soejono, 1977; Purusa Mahaviranata 1992; Chita Yuliati 1992).

Pada tahun 1995, survei penjajagan di sepanjang pantai utara daerah Buleleng telah berhasil menemukan Situs Nondalem. Desa Bondalem, Kecamatan Tejakula, Kabupaten Buleleng. Lokasi Situs Bondalem juga berada pada satuan lahan pedataran aluvial pantaii. Ketinggian Situs Bondalem kurang dari 5 meter, dan sangat dipengaruhi pasang surut air laut. Karakteristik temuan arkeologi berupa kubur terbuka dengan menggunakan wadah tempayan, dan temuan bekal kubur berupa tajak dan gelang perunggu, periuk, kendi, serta konsentrasi fragmen gerabah yang cukup padat (Sudiono, 1995).

Pada tahun 1961 di sepanjang tebing pantai Gilimanuk secara tidak sengaja oleh penduduk setempat menemukan sisa tulang manusia, pecahan gerabah, dan manikmanik. Sampai kini telah lcbih dari 14 tahap penelitian dilakukan sejak tahun 1962 sampai dengan tahun 1995. Situs Gilimanuk terletak di Desa Gilimanuk, Kecamatan Melaya, Kabupaten Jembrana, Propinsi Bali, atau terletak pada koordinat $8^{\circ} 9^{\circ} 36^{\prime \prime}$-- 
$8^{\circ} 12^{\prime} 59^{\prime \prime}$ Lintang Selatan, dan antara $114^{\circ} 25^{\prime} 57^{\prime \prime}-114^{\circ} 29^{\prime} 10^{\prime \prime}$ Bujur Timur. Secara geografis daerah Gilimanuk meruapakan semenanjung kecil di bagian barat Pulau Bali yang diapit oleh jasirah Prapat Agung. Situs Gilimanuk berada pada satuan lahan pedataran aluvial pantai yang berundak-undak dengan kemiringan lereng $0^{\circ}-5^{\circ}$, dan ketinggian 3-5 meter dari permukaan air laut.

Hasil yang diperoleh selama ini antara lain berupa cara-cara penguburan (tipe, orientasi) dengan menggunakan wadah (tempayan dan sarkofagus) dan tanpa menggunakan wadah, teknologi pembuatan dan fungsi guna gerabah, variabilitas benda bekal kubur, identifikasi rangka (jenis kelamin, estimasi usia mati, penyakit, ras), jenis dan tipologi manik-manik, pertanggalan C-14 terhadap individu-individu yang dikubur tanpa wadah, paleogeomorfologi wilayah Gilimanuk, komposisi unsur lempengan pentagonal perunggu, kualitas air sumur (rasa, bau, kandungan unsur, kesadahan, pangkat Hidrogen, konduk-tivitas, dan kekeruhan), identifikasi dan fungsi hewan vertebrata, dan lain-lain. Disamping kegiatan pengumpulan data, berbagai pendekatan telah pula diterapkan dalam peng-ungkapan pendukung budaya di Situs Gilimanuk baik ditiinjau dari aspek religi, teknologi, eokologi budaya, maupun populasi demografi (Soejono 1977, Wiwin Djuwita 1988, Santoso Soegondho 1993, Aziz 1995).

Situs Semawang terletak kurang lebih 10 meter sebelah selatan Pantai Sanur yang termasuk dalam Kecamatan Denpasar Selatan, Kabupaten Badung telah ditemukan secara tidak sengaja oleh penduduk setempat pada tahun 1986. Penelitian di Situs Semawang lebih bertujuan untuk mengumpulkan data kubur melalui kegiatan ekskavasi. Lokasi situs Semawang terletak pada koordinat $8^{\circ} 30^{\circ}--8^{\circ} 50^{\circ}$ Lintang Selatan, atau berada pada satuan lahan pedataran aluvial pantai pada ketinggian 4 meter di atas permukaan laut.

Hasil penelitian selama ini menunjukkan bahwa karakteristik temuan Situs Semawang berupa kubur tanpa wadah, pasu, periuk, dan cerat kendi, mangkuk dan cawan keramik, bingkai cermin perunggu, serta umur dan jenis kelamin rangka manusia yang dikuburkan membujur secara primer dengan ciri-ciri Ras Mongoloid dan Austromelanesid (Agus Suprijo, 1988).

Sebagian besar tujuan penelitian terhadap situs-situs dengan kandungan temuan kubur di atas sasaran utamanya adalah pengumpulan data sebanyak-banyaknya dengan strategi penelitian induktif, yaitu cara berpikir yang diawali dari sejumlah kasus individual untuk kemudian membuat kesim[ulan (generalisasi) yang bersifat umum. Pada dasarnya tujuan penelitian di atas merupakan usaha penjajagan (eksploratif) dan penggambaran (deskriptif) data kubur yang ada dalam kerangka bentuk, waktu dan "situs" sebagai satuan ruang analisis. Sementara itu, strategi penelitian deduktif dengan mengembangkan cara berpikir yang diawali dengan membuat pernyataan 
bersifat umum dan kemudian menuju kesimpulan yang bersifat khusus, masih jarang digunakan. Penjelasan data kubur, baik dalam kerangka bentuk, waktu, maupun dalam satuan analisis ruang 'wilayah' yang berkaitan dengan usaha untuk menjawab masalah 'mengapa' dan 'bagaimana' melalui penerapan model atau hipotesa dan teori tertentu masih jarang dilakukan.

\section{Pemanfaatan Data Kubur Bagi Studi Wilayah di Bali}

Penelitian Arkeologi merupakan rangkaian kegiatan logis, sistematis, obyektif, dan ilmiah yang berlandaskan metode ilmiah, dan bertujuan untuk mengkaji masalahmasalah arkeologi agar dapat dicapai suatu pengertian dan pemahaman prinsip-prinsip gejala masyarakat dan budaya masa lampau. Rangkaian kegiatan penelitian ini berguna untuk mengetahui apa, siapa, dimana, mengapa, kapan, dan bagaimana gejala-gejala arkeologi. Meskipun demikian, suatu penelitian arkeologi juga dapat dilakukan dengan berpedoman pada berbagai informasi penelitian terdahulu dengan tujuan untuk menambah ataupun menyempurnakan kajian tentang masyarakat dan budaya masa lampau. Penelitian yang bersifat strategis akan menghasilkan penelitian yang berorientasi pada masalah, memiliki maksud, tujuan dan sasaran (jangka pendek, menengah, dan jangka panjang). Demikian pula sasaran penelitian, baik jangka pendek, menengah, maupun jangka panjang dengan fokus kajian wilayah khususnya di Bali dapat diterapkan dengan memanfaatkan data kubur.

Salah satu jenis data arkeologi yang berkaitan dengan aktivitas pernukiman adalah data kubur. Faktor-faktor penentu bentuk data kubur dapat berupa benda-benda bentukan manusia (artefak), pertanda kegiatan manusia yang tak terpindahkan (feature), dan benda bukan buatan manusia dalam situs arkeologi (ekofak) konteks yang membalut benda (context), kaitan keruangan dengan benda temuan serta (asosiasi), sebaran benda (distribution) dalam satuan ruang situs maupun antar-situs dalam suatu kawasan tertentu (region), serta keletakan arbiterer dari titik ukur tertentu (provinience) (Sharer and Ashmore, 1980; Thomas, 1989, Renfrew and Bahn, 1991; Daud Tanudirjo, 1994). Dengan demikian data kubur dapat dipandang sebagai data yang berdiri sendiri. Artefak, ekofak, feature dalam konteks kubur merupakan suatu sistem yang berhubungan satu sama lain dalam kerangka bentuk, ruang, waktu, fungsi, dan proses. Oleh karena itu perlu diperhatikan pula beberapa kemungkinan seperti konteks sistem (tofonomi), proses-proses yang terjadi dalam sistem perilaku, serta proses-proses yang terdapat dalam transformasi peninggalan arkeologi (alam dan budaya).

Minat terhadap obyek kubur berupa palungan batu di Bali bermula dari laporan P. de Kat Angelino kepada P.A.J Mooijen pada tahun 1921. Peneliti selanjutnya, antara lain E. Evertsen (1925), V.E Korn (1928), P.V van Stein Callenfels (1930), dan R.P 
Soejono (1960) (Soejono, 1977). Hasil penelitian terdahulu dengan strategi penelitian induktif menunjukkan adanya pembentukan struktur yang kemudian bisa dikembangkan menjadi hipotesa-hipotesa untuk diuji.

Secara teoritis, pola sebaran sitsu-situs kubur di Bali yang telah diteliti dapat dianggap sebagai satu produk yang terwujud secara akumulatif dalam kurun waktu tertentu. Situs-situs kubur tersebut merupakan wujud konkret dari pola gagasan, pola perilaku, dan pola aktivitas masyarakat masa lalu berkenaan dengan penempatan, pengaturan, dan penyebaran, serta didasarkan atas satu atau sekumpulan pertimbangan (ideologisreligius, teknologis-ekologis, perilaku sosial, dan lain-lain). Dengan demikian berdasarkan hasil penelitian terdahulu dapat dikembangkan permasalahan baik berkenaan dengan gagasan (ideologi), tindakan, dan hasil budaya materi, maupun berkenaan dengan beberapa unsur kebudayaan (teknologi dan peralatan, kepercayaan/ religi, organisasi sosial, pengetahuan, kesenian, dan mata pencaharian/ekonomi).

Data kubur yang telah dikumpulkan dari penelitian terdahulu di beberapa situs wilayah Bali dapat dibedakan atas variabel (budaya) kubur dan variabel lingkungan fisik. Variabel (budaya) kubur yang berkaitan dengan aktivitas kubur dapat dibedakan atas kosmologi (siklus hidup), teknik penguburan, tipe pengebumian, jenis bekal kubur, jenis kelamin, usia, ras, penyakit, kronologi, dan sebagainya. Sementara itu variabel lingkungan fisik dapat dibedakan atas bentuk asal lahan, ketinggian, tanah, air, sisa hewan, dan lain-lain. Baik variabel budaya maupun variabel lingkungan tersebut dapat dikembangkan sebagai model yang berusaha menjelaskan hubungan sebab akibat yang saling mempengaruhi atau hubungan matematik dan statistik, serta model-model bentuk (analogi, ikonik, simbolik).

Pemanfaatan data kubur dapat memperdalam dan mempertajam strategi perencanaan penelitian yang lebih rinci, baik dalam skala ruang yang lebih kecil (meso dan mikro), maupun yang bersifat komparatif dan diakronis bagi pemahaman proses-proses budaya. Kualitas dan cara penanganan data kubur akan mempengaruhi pula tingkattingkat data arkeologi yang diperoleh, misalnya dari tingkat attribut, artefak, tipe, himpunan, sampai kumpulan himpunan dari beberapa situs dalam satuan kawasan geografis (topografis) yang sama. Oleh karena itu biasanya satuan analisis data kubur bersifat arbitrer (ditentukan oleh peneliti) sesuai dengan strategi dan sasaran yang ingin dicapai. 
Tabel 1. Korelasi Hirarki Artefak - Ruang - Manusia

\begin{tabular}{|c|c|c|}
\hline Hirarki Artefak & Hirarki Keluasan Ruang & Hirarki Manusia Pendukung \\
\hline $\begin{array}{c}\text { Budaya Arkeologi } \\
\Uparrow\end{array}$ & Kawasan & Masyarakat \\
\hline Himpunan & $\Uparrow$ & $\Uparrow$ \\
$\Uparrow$ & Regional/wilayah & Komunitas \\
\hdashline $\begin{array}{c}\text { Sub-Himpunan } \\
\text { T i p e } \\
\text { Artefak } \\
\text { Attribut }\end{array}$ & & Kelompok \\
\hline
\end{tabular}

Berdasarkan hasil budaya materinya dapat dihubungkan antara jenjang artefak dengan tingkahlaku manusia dalam skala ruang dan tingkatan manusia pendukungnya. Pada kategori artefak sebagai hasil buatan manusia mewakili ciri atau tindakan individu, misalnya hiasan atau bentuk gerabah. Pada kategori sub-himpunan yang diawali oleh berbagai jenis artefak dan memiliki kesamaan dari segi fungsi guna merupakan hasil tindakan sekelompok individu terbatas yang mengacu pada kategori ruang situs, misalnya jenis bekal kubur periuk tera jala. Kategori himpunan atau kumpulan beberapa bagian himpunan dengan fungsi yang berbeda mewakili komunitas dengan kategori ruang wilayah. Selanjutnya, kategori kebudayaan arkeologis atau kumpulan beberapa himpunan dari beberapa situs menunjukkan kegiatan atau tindakan suatu masyarakat pada satu kawasan tertentu, sebagai ruang yang paling luas (Sharer dan Ashmore, 1980).

Perilaku penguburan merupakan kenyataan tindakan yang tidak lepas dari unsur-unsur pengetahuan, kepercayaan, nilai dan norma, misalnya pengetahuan tentang kehidupan sesudah mati, kepercayaan upacara penguburan harus dilaksanakan menurut nilai dan norma aturan yang berlaku. Masalah tingkahlaku penguburan masa lampau dapat diterapkan dalam strategi penelitian dan analisa laboratorium. Misalnya, analisa pollen terhadap sampel sedimen yang diambil dari dalam kubur membantu kita dalam penarikan interpretasi berkaitan dengan proses pelaksanaan upacara penguburan masa lampau. Oleh karena data kubur merupakan cermin tingkahlaku masa lampau yang telah bias, maka perlu dipertimbangkan pula proses pembentukan benda arkeologis tersebut hingga kita temukan sekarang.

Schiffer (1976) telah menggambarkan model proses terbentuknya data arkeologi yang berubah karena faktor-faktor kegiatan manusia dan alam. Proses transformasi di atas perlu diperhitungkan dalam tingkat analisa dan interpretasi data kubur, yaitu bendabenda yang berperan dalam konteks sistem tingkahlaku penguburan pada masa lalu berubah menjadi benda atau artefak yang ditemukan dalam konteks arkeologi, atau aktivitas pakai ulang (reuse) benda yang berfungsi dalam kegiatan sehari-hari 
kemudian digunakan sebagai wadah menempatkan untuk sesuatu dalam kegiatan upacara penguburan, dan lain-lain. Dengan demikian data kubur juga dapat ditinjau dari hubungan antara bentuk, fungsi, dan proses, atau hubungan antara bentuk, ruang, dan waktu. Dalam kaitan ini peran analisa laboratorium, misalnya pertanggalan absolut C-14, komposisi unsur artefak (tanah liat, logam), pengamatan geomorfologigeografi dan analisa sedimentologi pada saat lahan digunakan sebagai lokasi penguburan dapat membantu penarikan interpretasi proses budaya yang terjadi dalam suatu wilayah.

Masalah gagasan atau ideologi misalnya, masyarakat Bali sampai kini memiliki pertimbangan ideologis, yaitu konsepsi kepercayaan ritual dan alam dalam pemilihan dan penataan ruang aktivitas bermukim. Penataan ruang permukiman di Bali didasarkan pada konsepsi gunung (kaja) dan laut (kelod). Orientasi ke arah gunung masih dianggap sebagai lokasi yang bersifat sakral, misalnya dalam penempatan bangunan suci (pura). Sebaliknya, orientasi ke arah laut dianggap bersifat profan, misalnya tempat pemukiman hunian. Dengan didasarkan pada bukti orientasi rangkarangka manusia masa lampau sebelum masuk pengaruh Hindu di Bali, maka diduga dasar konsepsi penataan ruang sakral - profan berasal dari pendukung budaya bercorak prasejarah.

Penerapan studi wilayah di Bali dengan memanfaatkan data kubur telah dilakukan oleh Soejono (1977), dan I Wayan Ardika (1987). Soejono telah memberikan gambaran distribusi dan sistem penguburan di Bali pada awal Masehi. Selanjutnya, benda-benda perunggu yang ditemukan dalam sarkofagus dihubungkan dengan surplus hasil panen padi yang mengakibatkan pula peningkatan kehidupan ekonomi masyarakat Balii masa lampau oleh I Wayan Ardika. Masih banyak lagi kemungkinan untuk memanfaatkan data kubur dengan mengembangkan model-model lain.

\section{Penutup}

Penelitian Arkeologi merupakan serangkaian kegiatan ilmiah secara sistematis yang bertujuan mengumpulkan dan mengembangkan pengetahuan guna mengungkapkan dan menjelaskan suatu gejala arkeologis dengan landasan kerangka berpikir tertentu. Pengembangan kerangka pikir dalam penentuan strategi penelitian sebagai alternatif sudah saatnya diperhitungkan dalam pelaksanaan penelitian masa kini.

Usaha pengembangan kerangka pikir dalam penentuan strategi penelitian sebaliknya berangkat dari mengevaluasi strategi, metode, serta hasil penelitian yang pernah atau yang akan dilaksanakan. Harus diakui bahwa masih banyak kendala yang dihadapi guna mengungkapkan masalah-masalah arkeologi di Indonesia, dan tidak heran bila keterlibatan bidang ilmu-ilmu lain yang terkait perlu dipupuk dan dikembangkan pula 
dalam strategi penelitian. Pemanfaatan kualitas data kubur dengan mengembangkan kerangka pikir yang berorientasi kepada wilayah dapat memberikan kontribusi bagi kebanggaan jatidiri bangsa. Hal ini telah terlihat dengan hasil penelitian situs kubur yang pernah dilakukan di Bali.

Bali, sampai kini dikenal dengan kekayaan nilai-nilai dan budaya yang bersifat unik Proses pembentukan budaya di beberapa wilayah. Bali memiliki perbedaan dan keragaman sejak masa plestosen sampai masa resen melalui proses terjadinya persentuhan komunitas-komunitas dari luar Bali. Dengan menerapkan kerangka pikir yang lebih sistematis, hasil penelitian arkeologi yang berorientasi wilayah dan kawasan Bali diharapkan dapat memberikan sumbangan bagi kajian kebudayaan nusantara. khususnya Bali diharapkan dapat memberikan sumbangan bagi kajian kebudayaan nusantara. Sumbangan di atas dapat berupa informasi gagasan ideologi maupun bentuk-bentuk fisik peninggalan masa lampau yang sampai kini masih tampak.

\section{KEPUSTAKAAN}

Agus Suprijo, 1988. "Jdentitas Rangka Situs Kubur Semawang, Sanur, dalam Rapat Evaluasi Hasil Penelitian Arekologi III, Pandeglang, Departemen Pendidikan dan Kebudayaan, Jakarta, hlm. 393-402.

Ardika, I Wayan, 1987. Bronze Artifacts and The Rise of Complex Society in Bali, Thesis Master of Arts, The Australian National University.

Daud Aris Tanudirjo, I 994. "Retrospeksi Penelitian Arkeologi di Indonesia". Pertemuan Ilmiah Arkeologi VI, Pusat Penelitian Arkeologi Nasional, Jakarta, hlm. 67-96.

Mindra Faizaliskandiar, 1988. "Manfaat Studi Pemukiman bagi Disiplin Ilmu Arkeologi ", dalam Diskusi Ilmiah Arkeologi VI, Ikatan Ahli Arkeologi Indonesia, Komisariat Daerah Jakarta dan J awa Barat, Jakarta, 11-12 Februari (belum terbit).

Mundardjito, 1982. "Pandangan Tafonomi dalam Arkeologi: Penilaian Kembali Atas Teori dan Metode ", Pertemuan 1lmiah Arkeologi JI, Pusat Penelitian Arkeologi Nasional, Jakarta, him. 497-509.

Mundardjito, nfn. (1995). Kajian Kawasan: Pendekatan Strategis Dalam Penelitian Arkeologi Di Indonesia Dewasa Ini. Berkala Arkeologi, 15(3), 24-28. https:// doi.org/10.30883/jba.v15i3.666 
Naniek Harkantiningsih, 1990. "Jenis dan Peletakan Bekal Kubur di Situs Semawang dan Selayar: Pola Kubur dari Abad ke-14-19", dalam Proceedings Analisis Hasil Penelitian Arkeologi I: Religi dalam Kaitannya dengan Kematian, Jilid II, Departemen Pendidikan dan Kebudayaan, Jakarta, hlm. 222-230.

Nurhadi Magetsari, 1989. "Kajian Wilayah dalam Arkeologi Beberapa Problematik Metodologis ", Pertemuan Ilmiah Arkeologi V, Ikatan Ahli Arkeologi Indonesia, Yogyakarta, hlm. 343-351.

Purusa Mahaviranata, 1992. "Kubur Terbuka Masa Prasejarah Kalanganyar. Buleleng", dalam Forum Arkeologi IV, Januari, hlm. 2-19.

Purusa Mahaviranata, 1994. "Penelitian Kubur Prasejarah di Bali: Suatu Kajian Artefaktual", makalah dalam Seminar Evaluasi Hasil Penelitian Arkeologi, Palembang, 11-16 Oktober (belum terbit).

Renfrew, Collin dan Paul Bahn, 1991. Archaeology: Theories, Methods and Practise, London, Thames and Hudson, 1991.

Sharer, Robert J. dan Wendy Ashmore, 1980. Fundamental of Archaeology, California.

Shiffer, M.B., 1976. Behavioral Archaeology, Academic Press, New York.

Sudiono dan Arfian, 1995. "Penelitian Arkeometri di Situs Sembiran. Kecamatan Tejalmla, Kabupaten Buleleng, Propinsi Bali", Laporan Penelitian Arkeologi Bidang Arkeometri, Pusat Penelitian Arkeologi Nasional, Jakarta.

Soejono, R. P., 1965. "Penyelidikan Sarkofagus di Pu/au Bali", Laporan Konggres 1lmu Pengetahuan Nasional II, jilid 6, Seksi D., Djakarta, Majelis Ilmu Pengetahuan Indonesia Departemen Urusan Research, him. 231-250.

Soejono, R. P., 1977. Sistim-sistim Penguburan pada Akhir Masa Prasejarah di Bali, Disertasi, Fakultas Sastra Universitas Indonesia, Jakarta.

Soejono, R. P., 1984. Jaman Prasejarah di Indonesia, Sejarah Nasional Indonesia, Jilid I, Jakarta, Balai Pustaka.

Wanny Rahardjo, 1989. "Manfaat Kajian Regional dalam Penelitian Arkeologi ", dalam Proceedings Pertemuan Ilmiah Arkeologi V, Jilid IV, Yogyakarta, 4-7 Juli. 


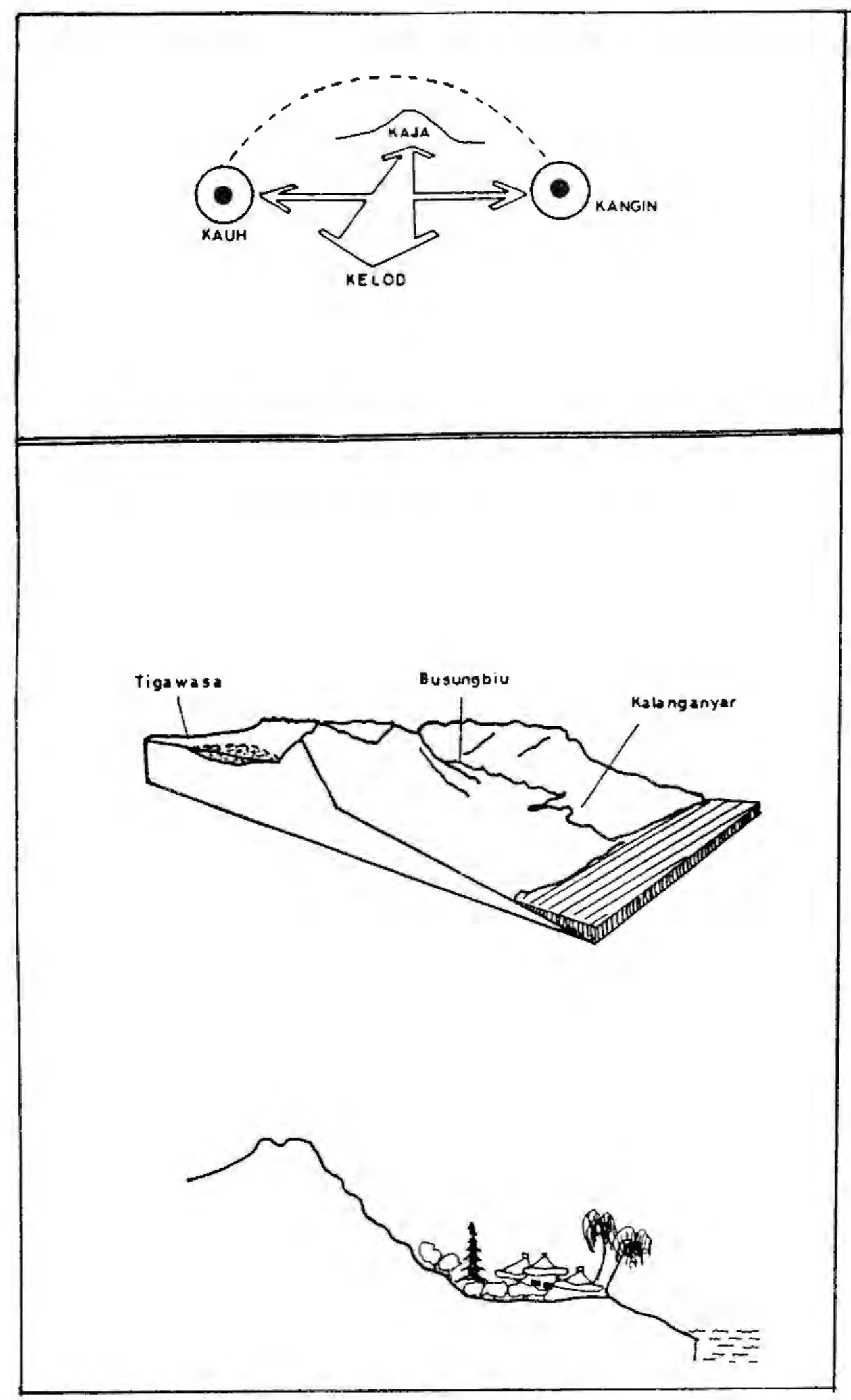

Gambar 1 Tata nilai dan pola penempatan beberapa Situs Kubur di Bali 